\title{
Reconstruction and Multiculturalism in the Scottish Nation-Building Project
}

Reconstruction et multiculturalisme dans le projet d'établissement de la nation écossaise

\section{Wafa El Fekih Said}

\section{(2) OpenEdition}

\section{Journals}

Electronic version

URL: http://journals.openedition.org/etudesecossaises/1418

ISSN: 1969-6337

\section{Publisher}

UGA Éditions/Université Grenoble Alpes

Printed version

ISBN: 978-2-37747-047-1

ISSN: 1240-1439

Electronic reference

Wafa El Fekih Said, « Reconstruction and Multiculturalism in the Scottish Nation-Building Project », Études écossaises [Online], 20 | 2018, Online since 01 April 2018, connection on 08 September 2020. URL : http://journals.openedition.org/etudesecossaises/1418

This text was automatically generated on 8 September 2020 .

(c) Études écossaises 


\section{Reconstruction and}

\section{Multiculturalism in the Scottish Nation-Building Project}

Reconstruction et multiculturalisme dans le projet d'établissement de la nation écossaise

Wafa El Fekih Said

1 The rise of nationalist movements around the world has had a significant impact on the politics of the different regions seeking self-determination as an ultimate objective. At the level of Scotland, the process of devolution has enabled political actors to develop their own responses on issues affecting Scotland. It is claimed that "a distinct Scottish political class has emerged, with its own career trajectory separate from the UK one" since devolution (Keating \& Cairney, 2006, p. 56). In this regard, consensus has been reached between political actors to reconstruct the nation (Meer, 2015) especially regarding key issues such as the need for immigration and the repopulation of the country.

2 In relation to immigration and integration policy, the nation-building project converges towards the creation of a "multicultural Scotland". The SNP, as a major political actor in Scotland has stressed on the contribution of ethnic minorities to the country and the importance of what is called "multicultural nationalism" as part of this endeavour (Hussain \& Miller, 2006). The notion of "multicultural nationalism" has been promoted by the political elite in Scotland. It is linked to a civic form of national identity and is based on territorial markers rather than an ethnic sense of belonging.

3 The main objective of this paper is to analyse and assess the political discourse on immigration and integration put in place by the political elite in Scotland. The historiography of scotland can be very revealing and insightful in relation to the context of the nation-building project which will constitute the first part of this chapter. 


\section{strategies envisaged by the main political parties in Scotland through a discourse} analysis of Scottish election manifestos.

Finally, the political discourses, advanced by the political elite as well as the multicultural rhetoric are evaluated in relation to the reconstruction of the nation.

\section{Historical perspective}

6 Since the 1990s, there has been a lot of talk on the future of Britain and the possible break-up scenario with the rise of nationalist calls for the independence of the Scottish nation. The separationist feelings and speculations have been consolidated in postdevolution Scotland with the rise of the SNP to power, raising questions on whether it is still possible to reconstruct a British identity in modern Scotland (Keating, 2009). However, Scottish national identity has not always had the same salience and expression; the nation is even said to have been living in a state of "hibernation" since the Act of Union 1707 (Nairn, 2001). This view of a Scottish identity being always present but to varying levels of expression is shared by Michael Keating who assumes that while a different sense of national identity in Scotland existed in the Middle Ages, no "timeless Scottish frame is available whenever the British one fails" (2009, p. 10). Thus, today's attempts to reconstruct the Scottish nation do not necessarily stand in contrast with the British one.

7 Similarly, interest in Scottish identity and its history as a separate and distinctive entity only started in the 1960s with the rise of Scottish nationalism. The study of Scotland as a distinctive entity from the rest of the UK has been motivated by different narratives of the break-up of the UK. ${ }^{1}$ There have been different and to a certain extent divergent views on the historiography of Scotland, some of which question the very existence of a distinct Scottish history after the Act of Union 1707. ${ }^{2}$ Different perspectives will be exposed in relation to the dominant narrative of Whig historiography.

8 In The Strange Death of Scottish History (1980), Marinell Ash claimed that by the late Victorian era interest in Scottish history became associated with "a narrow parochialism" resulting in the "death" of Scottish history in the mid nineteenth century with a failure to produce a nationalist historical consensus and a consistent national historiography. This idea was also supported by Colin Kidd, pointing out that interest in Scottish history in the late nineteenth century is seen as associated with parochialism (2003).

9 A different and more inclusive view of British historiography can be found in Linda Colley's Britons: Forging the Nation 1707-1837, which clearly reflected modern concern with British identity as related to English, Scottish and Welsh identities. Colley presented Britishness as an over-arching identity, which existed alongside attachments to the three nations of England, Scotland and Wales. The book primarily focused on the period between the Act of Union in 1707 and the accession of Queen Victoria in 1837 and its impact on the "forging" of British national identity. Following Anderson's theoretical approach ${ }^{3}$ on identity construction, Colley advanced the idea of superimposed and inclusive British national identity that started from the Act of Union 1707 (2009). The use of term "forging" can be very revealing as it both evokes the

Études écossaises, 20 | 2018 
idea of the "forming" and constructing of British identity, as well as the idea of imitating with the intention of fraud ${ }^{4}$. The word choice can be very revealing in the context of the Act of Union 1707, perceived by a number of Scots as being the result of bribery and corruption of members of the Scottish parliament.

Other historians such as the Duke of Argyll stressed the importance of the union, which enabled a distinctive national contribution to the history of Britain. Feelings of Englishness, Scottishness, Welshness and Irishness continued to coexist within one framework (1887). This more integrative view of British history contrasts with the interest generally dedicated to English history as exclusively synonymous with British history, a perspective chosen by Whig historians.

11 Colin Kidd follows the Whig interpretation of history arguing that Scottish history could only be expressed in relation to English history, which became the basis of British Whig identity. Kidd considered that what emerged from the Union of 1707 was not a unifying British national identity, but an "Anglo-British" identity which was essentially based on English values, customs and institutions. For Kidd (2003), this was an identity which was embraced by enlightened Scots. In this respect, pre-1707 Scottish history was critically dismissed from eighteenth-century historical literature. It was depicted simply in terms of feudal factions, political instability and economic backwardness, in stark contrast to the material progress of England in the medieval and early modern centuries. Therefore the only "usable past" for Kidd was English constitutional history. Thus, Scottish history can only be defined in terms of "Anglo-British" historiography.

The same argument of Anglo-British historiographical supremacy was expressed by Sir Henry Craik, Secretary of the Scotch Education Department (1885-1904) when he said that "from 1745 onwards the history of Scotland has hitherto been treated for the most part only as a subsidiary to the history of the empire" (1901). It seems, then, that the general prevailing view has so far been an "Anglo-British" Whig interpretation of history of the eighteenth and nineteenth centuries.

13 Tom Devine and Jenny Warmald in "Introduction: The Study of Modern Scottish History" (2012) claimed that Whig historiography cast a veil over the study of Scottish history. In this respect, Scottish history was dealt with exclusively as an adjunct to British history. Similarly, Tom Nairn used different historical accounts to argue for the presence of a strong Scottish identity concealed under Britishness, resulting in a long state of hibernation. Nairn admitted that long-term considerations of power and collective consciousness are more important than economic matters. He believed that Scottish identity has always been present but has been kept in "self-subordination" in order to guarantee the continuity and preservation of Scottishness without trouble.

14 The growing interest in Scottish history and Scottish national identity came with the idea that British national identity has been in decline since the end of the Second World War and has become a central motive in writings on national identity in Britain. Various factors can be seen as catalysts for debates on identity issues such as Irish independence, the rise of nationalist parties across Britain and the "end" of the empire with the independence of the majority of former British colonies. The rise of the SNP and its success in drawing attention to the home rule issue also spurred discussions about Scottish national identity and raised questions about the future of Britishness. Considering these different circumstances, "Scottishness" has gained new public interest in Scottish history developed as distinct from the rest of the UK. 


\section{A surviving distinctive sense of national identity Scotland}

In Political Discourse and National identity in Scotland (2012), Leith and Soule thoroughly examine the evolution of the political elite's discourse over identity in post-devolution Scottish elections' manifestos. The distinctiveness of Scotland can be found in the long tradition of institutional autonomy that was preserved following the Act of Union 1707, as explained in the following quote:

What mattered to the making and maintenance of Scots and Scotland was not a mawkish background glance at the past but an autonomous civil society made up of independent protestant church, autonomous local government and distinctively legal and education systems. (Quoted in Leith \& Soule, 2012, p. 3) $)^{5}$

Several studies have looked at Scotland's civic identity, attributing it to its distinctive church, legal and educational systems (Withers, 2001; Henderson, 2007). Thus, national identity has been essentially perpetuated through the institutions in Scotland. For Graeme Morton, "one national identity maintained through the institutions and civic culture of civil society, and another in the unthinking patriotism of the British state" (1998, p. 169). The result was a form of national identity overwhelmingly civic rather than ethnic (McCrone, 2002). In "Who Do You Say You Are? Making Sense of National Identities in Modern Britain" (2002), David McCrone highlighted the fact that there might be problematical issues of national and ethnic identities in Britain. Generally, in Scotland the concept of "national" or "civic" identities is used more than "ethnic" identity (McCrone, 2002).

The political elite also embraced this definition of Scotland as reflecting a civic, inclusive form of nationalism that stands in stark contrast with the more ethnic English nationalism. Therefore, post-devolution Scotland has revealed a new project to reconstruct a nation that is based on civic/territorial markers rather than on ethnic ones.

18 This vision of a civic inclusive multicultural Scotland can be found in political manifestos of the major political parties as it has been commonly embraced and promoted. Leith and Soule explore the way political parties refer to the civic form of identity through the personification of Scotland or what they call "national personification", an aspect that can be found in Scottish elections' manifestos. In fact, there are different instances where the nation is described a person and, thus, becomes "the embodiment of the same moral and political milieu as citizens" (Leith \& Soule, 2012), an example of that can be found in this quote from Labour manifesto "Scotland's diversity is a strength" (SLP, 2003, p. 39) or in this Conservatives' manifesto: "Scottish Conservatives understand that diversity is one of Scotland's defining characteristics as a country." (SCP, 1999, p. 25) Thus, Scotland, in its personification, is presented as diverse reinforcing the different political parties' commitment and welcoming towards multiculturalism. Leith and Soule (2012, p. 73) conclude that the different political parties eulogise the progressive nature of Scotland by presenting it as a civic and inclusive plurality. 


\section{Analysing and interpreting manifestos}

19 In this paper, the parties' visions of multiculturalism are studied in relation to the political manifestos they produced as the embodiment of their political ideology and commitments in an official form. Despite being less read than other sources of information like newspapers and dedicated websites, manifestos do represent the political statement of political parties in terms of key policy areas including immigration and integration. Therefore, the political manifestos of the 2016 Scottish election of the four major political parties have been chosen to be analysed in relation to multiculturalism.

20 The analysis will be limited to the manifestos of the four major political parties in Scotland, i.e. the Scottish National Party, the Scottish Labour Party, The Scottish Conservative Party, and the Scottish Liberal Democrats. This delimitation is restricted to the parties that are likely to be in power or to form the main opposition and thus to affect the politics of immigration and integration in a way or the other.

21 A discourse analytical approach following Jef Verschueren's method is adopted. An important characteristic of Verscheren's method is the importance dedicated to context in the discourse. The context in this case has multiple dimensions all very important in the research process. Verschueren (2011) stresses on the importance of focusing on detail without forgetting the broader picture. In the case of political manifestos, the need for a wider form of interpretation is important for the analysis. Context may be crucial to the way manifestos are formulated and may influence the discourse and the overall theme. This approach can be very relevant to this case study as the nationalist cause was given a chance to be advanced in the aftermath of the devolution referendum success. This also gave an opportunity to Scottish political parties to develop their own vision of politics.

22 Following these principles, the 2016 Scottish election manifestos will be analysed, focusing on elements such as the context, multi-modal aspects, as well as topics related to multiculturalism.

\section{Context}

23 The 2016 election for Scottish parliament was preceded by a Tory victory in the UK General Election of May 2015, an election where immigration and the refugee crisis were among the most important electoral issues. Another important electoral issue has been Europe, which reflects the degree of involvement of the UK in the concept of EU and European citizenship.

24 With its low support results in Scotland, the Conservative party's main concern revolved around gaining votes for a strong opposition. Scottish Labour presents a more ambitious objective of winning the election despite low support shown in the general election declining popularity in Scotland. In the meantime, the SNP's main objective is re-election after the failure of the much coveted independence referendum. 


\section{Multi-modal aspects} party leaders in different situations or other party members as well as photos of members of the civil society accompanied by their testimonies. In other cases photos with tangential relation to the surrounding text are used. The use of photos of people from black and ethnic minority backgrounds becomes very relevant and revealing as it can be intentional and carries a message.

In relation to the research topic of multiculturalism, only Scottish Labour and SNP included photos evoking minorities. Labour's manifesto contains a photo of two women wearing the Punjabi Junction restaurant slogan, under the "Welcoming communities" section, reflecting a quite stereotypical image of multiculturalism being associated with exotic food, featuring two smiling women, to evoke a successful integration in Scotland. The photo is a clear reference to the Sikh community in Glasgow, which constitutes one of the most important minority groups in the region.

Photo from Scottish Labour manifesto, Section "Welcoming Communities".
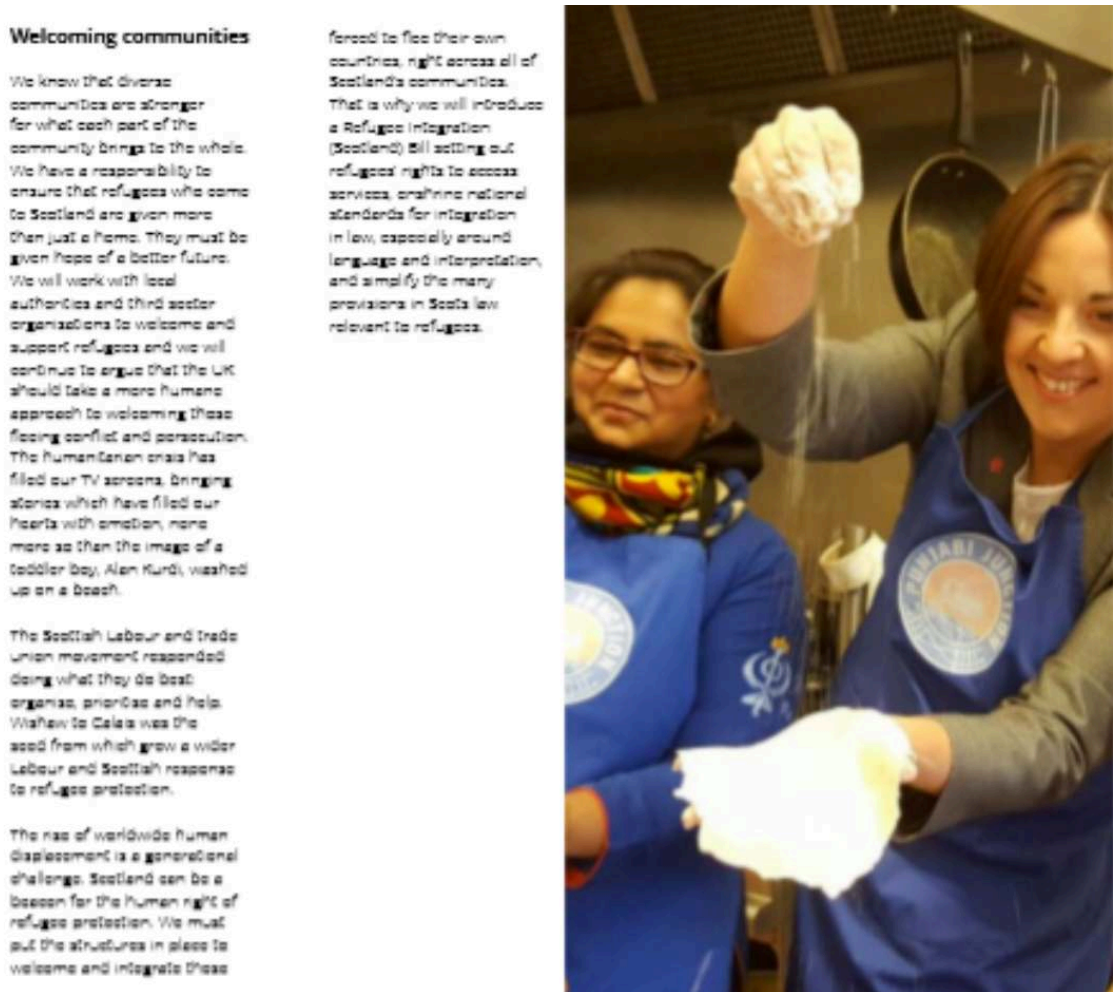

The SNP manifesto contains a number of photos of people from ethnic origins in different situations-one photo is with the First Minister Nicola Sturgeon with people from different minority groups, looking towards the camera. This photo reflects the multicultural aspect of SNP members and supporters and reinforces the fact that the SNP is a party that supports multiculturalism and encourages the involvement of minorities in politics and government positions. Another photo shows a black woman, seemingly in a work environment, showing enthusiasm in her job.

A third photo involving people from minorities in the SNP manifesto is of Roza Salih, a refugee from Kurdistan, in addition to her testimony of living in Scotland. Roza Salih 
smiles and appears relaxed in the photo, hinting to the inclusiveness and welcoming nature that can be found in Scotland. All three photos reflect a successful integration and inclusiveness.

\section{Photo from the SNP manifesto representing Roza Salih and her testimony.}

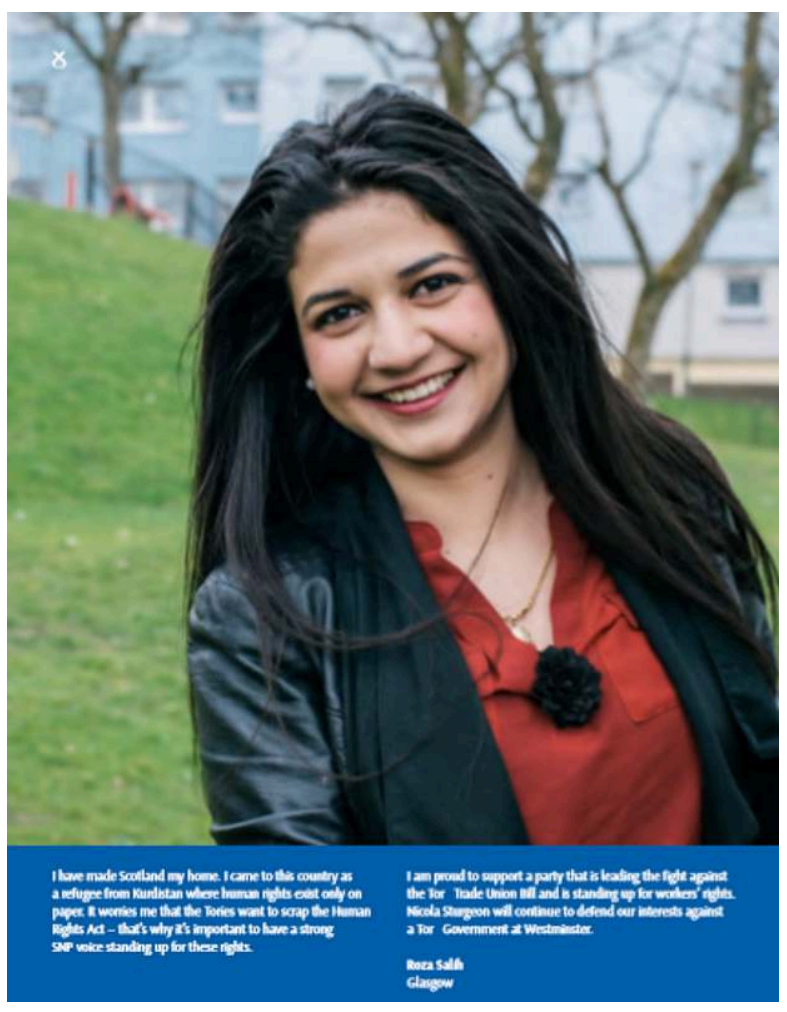

\section{Discourse analysis of topics/issues related to multiculturalism}

The SNP dedicates much attention to the topic of diversity, first by adding a testimony from a refugee from Kurdistan with her testimony on living in Scotland. Rosa Salih states:

I have made Scotland my home. I came to this country as a refugee from Kurdistan where human rights exist only on paper. It worries me that the Tories want to scrap the Human Rights Act-that's why it's important to have a strong SNP voice standing up for these rights. (SNP, 2016, p. 22)

Roza Salih refers to Scotland as "my home", reinforcing the multicultural aspect of Scotland, and acknowledges the SNP's role in securing her rights as refugee. This reflects the party's commitment to the refugees' cause which coincides with the "Welcome Refugees" campaign launched in $2015 .{ }^{6}$ The party clearly asserts its pledge to continue supporting the refugees coming to Scotland and providing them with the possibility of tuition-free studies. The SNP dedicates a subsection-"Diverse but equal"-to diversity, stressing on the importance of inclusion of minorities and announcing the assignment of a new race framework advisor to tackle inequalities.

Equality is stressed throughout different sections of the manifesto. For example, the initiative of providing a training for children on equality and to inclusive strategies and the "stress on tolerance, respect, human rights, equality and good citizenship" under 
the section "Improving child health", showing a special focus on equality that needs attention from childhood (SNP, 2016, p. 4). competing parties when dealing with multiculturalism and ethnic minorities. Consensus can be seen among political parties over the importance of multiculturalism and diversity as an electoral issue (except the Scottish Conservatives as the only party that did not make any reference to ethnic minorities). Diversity is mentioned especially in relation to the Syrian refugees and the need to provide a solution for the issue. The focus on refugees can be seen as directly linked to the immediate context of the refugee crisis in Calais as well as a continuation of the campaign of welcoming refugees started by the SNP. The multicultural aspect of Scottish society is also reinforced through the use of multi-modal aspects for the Scottish Labour and SNP manifestos.

Another important point of consensus is the focus on equality as an important electoral topic displayed by all parties with reference to specific groups. It is also worth noting the importance given to Gaelic language, which was referred to as an essential part of 
Scottish culture. Apart from reflecting the country's linguistic and cultural diversity, Gaelic is generally promoted by the political parties in order to highlight Scotland's distinctiveness from the rest of the UK. In fact, Gaelic, despite being spoken only by $1.7 \%$ of the total Scottish population (Scotland Census, 2015), it does hold a symbolic importance for Scots as part of Scottish identity and heritage. In a census performed by the Scottish government in 2011 on attitudes towards the Gaelic language, $40 \%$ of the total sample stated that Gaelic was important to their sense of national identity and some $17 \%$ claimed that it was very important. The polls reflect a widespread and strong agreement that Gaelic traditions should not be lost, and that Gaelic is an important part of Scottish culture (Graham \& West, 2011). Gaelic is also important in defining a separate political identity for Scotland from the UK hence the need for political parties to embrace and affirm that distinctiveness and to provide a Scottish dimension for their electoral promises.

The main challenge for political parties in relation to national identity is to be able to dissociate themselves from their British counterparts and to show and prove their commitment to Scottish national identity. The exception to this rule is for the SNP, which according to Leith and Soule (2012, p. 40) presents the advantage of presenting candidates only for Scotland, thus becoming unlikely to present an incoherent political discourse. The SNP has even declared itself as "Scotland's party" in the 1999 election manifesto.

It is clear that the political parties in Scotland are working on reconstructing a nation that is distinctive from the rest of the UK in its approach towards multiculturalism as three of the four analysed manifestos give much importance to diversity and to the current refugee crisis, and also in its focus on equality as one key electoral issues, equality being one of the main issues that differentiates Scotland from the rest of the UK. The commitment to Gaelic language and culture can be seen as reflective of the attempt to dissociate Scotland's identity from the British one and as symbolic of the already culturally rich Scottish identity. The intentions of political parties in this choice for a multicultural approach to integration can be questioned but, as Nasar Meer $(2015$, p. 2) points out, the elite political actors can play a crucial role in ensuring that appeals to nationhood in Scotland can be meaningfully calibrated to include minorities too in contrast with the more hostile discourse South of the border.

\section{Conclusion}

The present paper sums up the main discourse over multiculturalism as advanced by the political elite in Scotland. This is performed through a discourse analysis of the 2016 Scottish election manifestos as presented by the main political parties. A clear endorsement of diversity and multiculturalism is noticeable with particular reference to refugees and the need to deal with them, showing the importance of context in shaping policy decisions. The consensus displayed by the different parties may be may be prescribed in the main objective of reconstructing the Scottish nation, a status clearly affirmed that challenge the different Anglo-Whig historiographical accounts the exclusive existence of a British identity. 


\section{BIBLIOGRAPHY}

AsH Marinell, 1980, The Strange Death of Scottish History, Ramsay Head Press.

Brown Alice, MCCRONE David \& PATERson Lindsay, 1996, Politics and Society in Scotland, London, Macmillan.

Colley Linda, 2009, Britons: Forging the Nation, 1707-1837, Yale University Press.

CRAIK Henry, 1901, A Century of Scottish History, Edinburgh, W. Blackwood and Sons.

HENDERSON Ailsa, 2007, Hierarchies of Belonging: National Identity and Political Culture in Scotland and Quebec, McGill-Queen's Press.

HUSSAIN Asifa M. \& MilleR William L., 2006, Multicultural Nationalism, Oxford, Oxford University Press.

KEATING Michael, 2004, "European Integration and the Nationalities Question", Politics \& Society, vol. 32, no. 3, pp. 367-88.

Keating Michael \& Cairney Paul, 2006, "A New Elite? Politicians and Civil Servants in Scotland after Devolution", Parliamentary Affairs, vol. 59, no. 1, pp. 43-59.

KeAting Michael, 2009, The Independence of Scotland: Self-Government and the Shifting Politics of Union, Oxford, Oxford University Press.

KIDD Colin, 2003, Subverting Scotland's Past: Scottish Whig Historians and the Creation of an AngloBritish Identity 1689-1830, Cambridge, Cambridge University Press.

LEITH Murray Stewart \& Soule Daniel P. J., 2012, Political Discourse and National Identity in Scotland, Edinburgh, EUP.

MEER Nasar, 2015, “Looking Up in Scotland? Multinationalism, Multiculturalism and Political Elites”, Ethnic and Racial Studies, vol. 38, no. 9, pp. 1477-96. Available on <https://doi.org/ 10.1080/01419870.2015.1005642>.

MORTON Graeme, 1998, “What If?: The Significance of Scotland's Missing Nationalism in the Nineteenth Century", in D. Broun, R. J. Finlay \& M. Lynch (eds), Image and Identity: The making and Re-Making of Scotland Through the Ages, Edinburgh, John Donald, pp. 157-76.

NAIRN Tom, 1977, The Break-Up of Britain. Crisis and Neo-Nationalism, London, New Left Books.

NAIRN Tom, 2001, After Britain: New Labour and the Return of Scotland, Granta Books.

PATERSON Lindsay, 1994, The Autonomy of Modern Scotland, Edinburgh, Edinburgh University Press. SCOTTISH CONSERVATIVE PARTY (SCP), 1999, Scottish Conservative Party Manifesto: Scotland First. SCOTTISH CONSERVATIVE PARTY (SCP), 2016, Scottish Conservative Party Manifesto: A Strong Opposition A Stronger Scotland.

SCOTTISH LABOUR PARTY (SLP), 2003, Scottish Labour Party Manifesto: On Your Side.

SCOTTISH LABOUR PARTY (SLP), 2016, Scottish Labour Party Manifesto: Invest in Scotland's Future.

SCOTTISH LIBERAL Democratic PARTY (SLDP), 2016, Scottish Liberal Democratic Party Manifesto: Be the Best Again.

SCOTTISH NATIONAL PARTY (SNP), 2016, Scottish National Party Manifesto: Re-Elect. 
VERSCHUEREN Jef, 2011, Ideology in Language Use and Ideology: Pragmatic Guidelines for Research, Cambridge, Cambridge University Press.

WITHERS Charles W. J., 2001, Geography, Science and National Identity: Scotland since 1520, Cambridge, Cambridge University Press.

\section{Internet material}

DEVINE T. M. \& WARMALD Jenny, 2012, "Introduction: The Study of Modern Scottish History", in T. M. Devine and J. Warmald (eds), The Oxford Handbook of Modern Scottish History, Oxford, Oxford University Press. Available on <www.oxfordhandbooks.com/view/10.1093/oxfordhb/ 9780199563692.001.0001/oxfordhb-9780199563692-e-1?print=pdf> (accessed 6 March 2018).

GRAHAM Alastair \& WeSt Catriona, 2011, “Attitudes Towards the Gaelic Language”, Social Research. Research Findings, no. 7. Available on <www.gov.scot/Resource/Doc/355398/0120024.pdf> (accessed 6 July 2017).

McCrone David, 2002, "Who Do You Say You Are? Making Sense of National Identities in Modern Britain", Ethnicities, vol. 2, no 3, pp. 301-20. Available on <http://journals.sagepub.com/doi/abs/ $10.1177 / 14687968020020030201>$ (accessed 6 July 2017).

SCOTland Census, 2015, “Scotland's Census 2011: Gaelic Report (Part 1)”, National Records of Scotland. Available on <www.nrscotland.gov.uk/news/2015/scotlands-census-2011-gaelic-reportpart-1> (accessed 30 October 2017).

\section{NOTES}

1. See Nairn (1977) for example.

2. Whig historiography was the dominant narrative until the 1960s. It favoured the idea of an Anglo-British prevailing history that developed since 1707.

3. Benedict Anderson's work draws on the idea that identity can be imagined and thus reinvented and re-constructed according to changing social, political and economic situations.

4. Definition from Merriam-Webster Dictionaries.

5. The citation represents the view of the Edinburgh modernist thinkers as can also be found in Brown et al. (1996, p. 5) and Paterson (1994, pp. 3-45).

6. The \#WelcomeRefugees campaign is an initiative from the Scottish government in reaction to the Refugee crisis following the war in Syria. For more information on the Scottish government work: <www.gov.scot/Publications/2017/03/5825/8>.

\section{ABSTRACTS}

Since the 1980s, there has been debate on the future of nation-states with the rise of nationalist movements in the UK, bringing to light new forms of territorial politics (Keating, 2004). At the level of Scotland, the process of devolution has had significant changes on local parties' policies. It has enabled political actors to develop their own responses on issues affecting Scotland. As 
part of the nation-building project, a consensus has been reached between political actors to reconstruct the nation (Meer, 2015). One of the tenets of this nation-building project is the creation of a "multicultural Scotland" and this curious intersection between nationalism and multiculturalism raises questions about the effectiveness of multicultural strategies within a nationalist autonomist framework.

This paper attempts to analyze and assess how political actors are positioning minorities within the nation-building project and to what extent this narrative is inclusive of ethnic minorities' claims. It puts into perspective the idea of the nation-building project in Scotland through putting forward the historical perspective with an overview of the historiography of Scotland. Besides, the evolution of the narratives over multiculturalism and the involvement of ethnic minorities in the reconstruction of the nation will be analysed through a discourse analysis of the main parties' manifestos. The last part is dedicated to an evaluation of the political elite's attempt to reconstruct the nation through advancing a multicultural modal.

Depuis les années 1980, le débat sur l'avenir des nations-États ne cesse d'évoluer avec le développement des mouvements nationalistes au Royaume-Uni, dans le contexte de politiques territoriales (Keating, 2004). Au niveau de l'Écosse, le processus de décentralisation a eu un impact profond sur la politique régionale. Cela a permis aux acteurs politiques de formuler leur propre vision sur des questions affectant l'Écosse dans le cadre d'un projet de reconstruction du pays (Meer, 2015). Un des piliers de ce projet est la création d'un modèle multiculturel d'intégration. Certes, une intersection entre nationalisme et multiculturalisme peut soulever des questions sur l'efficacité d'une telle approche multiculturelle en Écosse surtout dans le cadre du projet nationaliste d'autonomie.

Cet article tente d'analyser et d'évaluer le discours politique en Écosse en mettant l'accent sur le modèle d'intégration envisagé ainsi que la place des minorités dans le projet de reconstruction de l'Écosse. La mise en perspective de ce projet nécessite une approche historique et historiographique de la création de l'Écosse. En outre, une analyse des récits et discours électoraux permettra d'évaluer le discours multiculturel en Écosse et l'implication des minorités ethniques dans ce discours.

\section{INDEX}

Mots-clés: multiculturalisme, dévolution, minorités, manifestes politiques

Keywords: multiculturalism, devolution, minorities, party manifesto

\section{AUTHOR}

\section{WAFA EL FEKIH SAID}

Université Toulouse - Jean Jaurès, Cultures anglo-saxonnes.

Wafa El Fekih Said is currently finishing her $\mathrm{PhD}$ at Université Toulouse Jean Jaurès - CAS

(Cultures anglo-saxonnes) Research centre, under the supervision of Professor Jean Berton. Her thesis is entitled The Evolution of the Political Discourse over Immigration and Integration in Postdevolution Scotland. She has presented papers on Delimiting the Concept of Multiculturalism within the Context of Scotland at the conference of PhD students of CAS entitled "Délimitations", Perception of Criminality among Migrants \& the Myth of Equality in Scotland at the conference of the French Society for Scottish Studies (SFEEC) entitled "Le crime, le châtiment et les Écossais", and Confluence and Integration in Scotland? at the conference of SAES entitled "Confluence(s)". 
Wafa El Fekih Said, étudiante en quatrième année de doctorat à l'université Toulouse Jean Jaurès - Laboratoire CAS (Cultures anglo-saxonnes), sous la direction du professeur Jean Berton. Titre de la thèse : The Evolution of the Political Discourse over Immigration and Integration in Post-devolution Scotland. Communications présentées : Delimiting the Concept of Multiculturalism within the Context of Scotland, à la Journée d'études des doctorants du CAS « Délimitations » (Université Toulouse Jean Jaurès, 30 janvier 2015) ; Perception of Criminality among Migrants \& the Myth of Equality in Scotland, au Colloque SFEEC « Le crime, le châtiment et les Écossais » (Université Toulouse Jean Jaurès, 14 janvier 2016) ; Confluence and Integration in Scotland?, au Congrès SAES « Confluence(s)» (Université Jean Moulin - Lyon 3, 3 juin 2016). 